\title{
INTENDED USE OF REAL ESTATE AS A TIME CHANGEABLE ATTRIBUTE FOR DETERMINING COMPENSATION FOR NATIONALIZED AND EXPROPRIATED LANDS ${ }^{1}$
}

\author{
Tomasz Adamczyk, PhD \\ AGH University of Science and Technology \\ Department of Geomatics \\ e-mail: tomasz.adamczyk@agh.edu.pl \\ Agnieszka Bieda, PhD \\ AGH University of Science and Technology \\ Department of Geomatics \\ e-mail: agnieszka.bieda@agh.edu.pl
}

\begin{abstract}
Constitutional transformation in Poland, which took place at the turn of the eighties and nineties of the past century, was directed, among others, at creating a civil society and a free market. Changes in people's mentality quickly brought about economic changes based on the concept of private ownership. Yet one should remember that in the period preceding this time, personal assets were significantly limited. Many people's assets were repossessed by the state in nationalization or expropriation processes.

Present regulations permit getting these assets back. This is possible in cases when the repossessed real estate was misused with the purpose of expropriation, or it became needless. Real estate is also reacquired via invalidation of administrative decisions or provisions of law. Real estate owners and their legal successors can apply to get back real estate. It is possible to get compensation for assets which cannot be taken back in actuality, which should correspond with the actual value of the lost rights. The level of compensation should be determined on the basis of real estate market value. This value is determined for the day the decision to determine compensation is issued, taking into account the state and purpose of the real estate on the day the document approving the repossession of the real estate was prepared.

The authors present changes in law provisions connected with spatial planning in Poland from the year 1946, when the first decree connected with this topic entered into force, to this day. They describe documents kept in state archives which should be used by valuers. They also show, on the basis of examples, how important the correct determination of the intended use of real estate is, taking into account documents that have been created over the years.
\end{abstract}

Key words: land use plan, nationalization, compensation, general plan, expropriation.

JEL Classification: R30, D03, D70.

Citation: Adamczyk T, Bieda A., 2014, Real estate purpose, as time changeable attribute, for determination of compensation for nationalized and expropriated lands, Real Estate Management and Valuation, vol. 22, no. 4, pp. 35-50.

DOI: $10.2478 /$ remav-2014-0035

\footnotetext{
${ }^{1}$ This work was financed from a research fund realized at the AGH University of Science and Technology, allocated for the year 2014.
} 


\section{Introduction}

The first half of the twentieth century is a time when Poland reappeared on the map of Europe and an attempt at reconstructing the country following the damages brought about by the Second World War. Doctrines which dominated on the world political scene at the time quickly led to the rebuilding of the political system in Poland. This caused individual ownership to become a secondary issue for many years. The most important thing was to establish a strong and safe state. In order to do so, it was decided that personal assets be repossessed. This was done through nationalization and expropriation processes, the aim of which was to form a new legal status of real estate. Such a situation could have lasted up until now if not for the constitutional changes which took place at the turn of eighties and nineties of the past century.

The formation of a civil society and creation of a free market very quickly brought about changes in the way of thinking and perception of all aspects of life. The economy became based on individual ownership, thus legal provisions that made it possible to recover property that had been unrightfully repossessed in former system had to be created. Since it is not always possible to restitute such property, aggrieved persons can apply for compensation corresponding to the actual value of the lost rights or even more, accounting for the profits that the repossessed real estate could have brought.

The amount of compensation owed is determined on the basis of the market value of real estate which had been lost. It is determined accounting for the state and intended use of the real estate on the day of its repossession or limitation of rights to it, and values of similar real estate on the day of the decision regarding compensation is issued. Therefore, when determining the value of real estate that is the basis for determining compensation, the valuer must take into account both, the state and intended use of the real estate on the day the owner was actually deprived of his/her rights to it. This problem is well-known in practice and very often reported in literature, for example (MENDELSON 1985; MulLER 1981; NOSAL 2001; SCHACHTER 1984; ŚLIWIŃSKI 2011; TREMBECKA, KWARTNIK-PRUC 2010; ŹRÓBEK, WALACIK 2008; ŹRÓBEK 2008; ŹRÓBEK, ŹRÓBEK 2008). One can also find works dealing with lost profits (FILIPIAK 2007a; FILIPIAK 2007b; WALACIK 2011). But despite the fact that there are many papers concerning spatial planning in valuation, such as BIEDA et al. (2012) or CYMERMAN (2011), determining the historical purpose of real estate can lead to some difficulties.

Incorrectly determined intended use of real estate can significantly distort the final value of compensation. Thus, it must be determined carefully, on the basis of appropriate documents.

\section{Nationalization versus expropriation}

The Constitution of the Republic of Poland assures the protection of ownership rights. However, it gives two ways of interfering with this right (SUCHAR 2012). These are statutory limitations ${ }^{2}$ and expropriation ${ }^{3}$. According to a verdict of the Constitutional Tribunal ${ }^{4}$, the first of them are created via general acts, and are established in the common interest. Expropriation, by contrast, confiscates or limits, for public purposes, rights to a specific real estate. It is carried out for the benefit of the authorized side, through an administrative decision.

Nationalization is usually perceived negatively, as the unpaid repossession of ownership rights by the State Treasury, usually against the owner's will (WOLANIN 2008). Yet, from the legal point of view, one should understand it as the repossession of real estate, belonging to specific category of assets, or from a specific group of owners on behalf of public authorities. No additional activities have to be undertaken in order for real estate to be repossessed via the nationalization process (SUCHAR 2012).

Therefore, the term "nationalization" concerns, first of all, the unpaid conveyance, on behalf of the State Treasury, of ownership rights to:

- agricultural real estate in order to carry out the agrarian reform in 1944 ,

- forest real estate in $1944^{6}$,

\footnotetext{
2 art. 31 ust. 3 oraz art. 64 ust. 3 Konstytucji Rzeczypospolitej Polskiej z 2 kwietnia 1997 r. (Dz. U. z 1997 r. nr 78, poz. 483, z późn. zm.) [Constitution of the Republic of Poland of 2 April 1997 (Journal of Laws of 1997, No. 78, item 483, as amended)] ${ }^{3}$ art. 21 ust. 2 Konstytucji Rzeczypospolitej Polskiej Polskiej z 2 kwietnia 1997 r. (Dz. U. z 1997 r. nr 78, poz. 483, z późn. zm.) [Constitution of the Republic of Poland of 2 April 1997 (Journal of Laws of 1997, No. 78, item 483, as amended)]

${ }^{4}$ Orzeczenie Trybunału Konstytucyjnego z 28 maja 1991 r., sygn. K1/91 [Verdict of Constitutional Tribunal of 28 May 1991]

${ }^{5}$ Dekret Polskiego Komitetu Wyzwolenia Narodowego z 6 września 1944 r. o przeprowadzeniu reformy rolnej (Dz. U. z 1944 r. nr 4 poz. 17, z późn. zm.) [Decree of Polish Commitee of National Liberation of 6 September 1944 - on the Execution of the Agrarian Reform (Journal of Laws of 1944, No. 4, item 17, as amended)]
} 
- abandoned estates and those formerly owned by Germans in 1946 7,

- assets remaining under state management in $1958^{8}$.

The nationalization process is also associated with the repossession of companies by the State of Poland (after issuing an individual decision regarding nationalization), on the basis of the Act of 1946, which aimed to reconstruct the national economy, assure economic sovereignty of the State and improve general prosperity; it also served to convey ownership rights to real estate being located within the area of the capital city of Warsaw on behalf of the gmina (commune), which took place on the basis of the so called Bierut Decree ${ }^{9}$. The purpose of land seizure was to allow the rational rebuilding and future development of the capital.

Despite the fact that nationalization is not permissible under the contemporary Constitution, one can recognize the following as a specific type of nationalization:

- repossession on 1 January 1999, by the State Treasury or local government unit, real estate occupied for public roads and remaining in their possession on 31 December 199810 (MZYK 2008),

- repossession, by the State Treasury or local government unit, of parcels designated for public roads on the day when the decision accepting the division was finalized or the court verdict became valid ${ }^{11}$ (WOLANIN 2008).

Expropriation, by contrast, is individual repossession - it concerns a specific entity and aims to fulfill a clearly defined need (WIERZBOWSKI 2011, p. 409). What distinguishes expropriation from nationalization is the legal form legitimizing these procedures (SUCHAR 2012). According to the decision of the Constitutional Tribunal, 12 the approval of expropriation by administrative decision is supported by the fact that is must be differentiated from the forbidden nationalization. The judges emphasized the fact that if expropriation were to be understood generally as any depravation of ownership without regard to its form, there would no longer be clear differences between the two.

The current definition of expropriation is found in the Act on Real Estate Management.

1. The object of expropriation is real estate (land, developed land, buildings, dwellings).

2. Expropriation is connected with the deprivation of the ownership right to real estate, limitation of this right (through issuing a building permit for objects of technical infrastructure or permission for running a business connected with mineral exploration and extraction), or the removal of a limited property right to real estate (i.e., regarding use, easement, cooperative housing right to a dwelling).

3. Expropriation may concern the entire real estate or its part.

4. The Deprivation or limitation of a right can take place only on behalf of the State Treasury or local government unit.

5. Expropriation is possible only when it is essential to the realization of public purposes described in the Act on Real Estate Management ${ }^{13}$ or in separate provisions (recorded in the local land use plan or decision on the location public purpose investments).

6. For expropriated real estates, equitable compensation is to be owed (money equivalent or replacement real estate).

\footnotetext{
${ }^{6}$ Dekret Polskiego Komitetu Wyzwolenia Narodowego z 12 grudnia 1944 r. o przejęciu niektórych lasów na własność Skarbu Państwa (Dz. U. z 1944 r. nr 15 poz. 82) [Decree of Polish Commitee of National Liberation of 12 December 1944 - on Repossession of Some Forests on Behalf of the State Treasury (Journal of Laws of 1944, No. 15, item 82)]

${ }^{7}$ Dekret z 8 marca 1946 r. o majątkach opuszczonych i poniemieckich (Dz. U. z 1946 r. nr 13, poz. 87) [Decree of 8 March 1946 on Abandoned Estates and those Formerly Owned by Germans (Journal of Laws of 1946, No. 13, item 87)]

${ }^{8}$ Ustawa z 25 lutego 1958 r. o uregulowaniu stanu prawnego mienia pozostającego pod zarządem państwowym (Dz. U. z 1958 r. nr 11 poz. 37, z późn. zm.) [Act of 25 February 1958 - on Regulation of Legal Status of Assets under State Administration (Journal of Laws of 1958, No. 11, item 37, as amended)]

${ }_{9}^{9}$ Dekret z 26 października 1945 r. o własności i użytkowaniu gruntów na obszarze m. st. Warszawy (Dz. U. 1945 r. nr 50, poz. 279) [Decree of 26 December 1945 - on Land Ownership Right and Use Within the Area of the Capital City Warsaw (Journal of Laws of 1945, No. 50, item 279)]

${ }^{10}$ art. 73 ust. 1 ustawy z 13 października 1998 r. - Przepisy wprowadzające ustawy reformującej administrację publiczną (Dz. U. z 1998 r. nr 872, poz. 133, z późn. zm.) [Provisions of 13 October 1998 Introducing Acts reforming Public Administration (Journal of Laws of 1998, No. 872, item 133, as amended)]

11 art. 98 ust. 1 ustawy z 21 sierpnia 1997 r. o gospodarce nieruchomościami (Dz. U. z 2010 r. nr 102, poz. 651, z późn. zm.) [Act of 21 August 1997 - on Real Estate Management (Journal of Laws of 2010, No. 102, item 651, as amended)]

${ }_{12}$ Wyrok Trybunału Konstytucyjnego z 21 czerwca 2005 r., sygn. P25/02 [Verdict of Constitutional Tribunal of 21 June 2005]

13 art. 6 ustawy z 21 sierpnia 1997 r. o gospodarce nieruchomościami (Dz. U. z 2010 r. nr 102, poz. 651, z późn. zm.) [Act of 21 August 1997 - on Real Estate Management (Journal of Laws of 2010, No. 102, item 651, as amended)]
} 
7. Expropriation takes place by means of administrative procedure, through the decision of the starost (district governor) ${ }^{14}$.

8. Expropriation is permissible only in the case when a public purpose cannot be realized in any other way but through the deprivation or limitation of property rights, and the given real estate cannot be acquired by the State Treasury or local government unit through civil contract.

The term "expropriation" has been shaped for years. Before expropriation was enunciated in the Act on Real Estate Management, it was mentioned in:

- the Decree of 7 April 1948 on the Expropriation of Properties Repossessed for Institutional Purposes during the War of 1939 - 1945 (Journal of Laws of 1948, No. 20, item 138, as amended),

- Decree of 26 April 1949 - on Acquiring and Conveying Real Estates Necessary for the Realization of National Economic Plans (Journal of Laws of 1949, No. 27, item 197, as amended),

- Act of 12 March 1958 - on Rules and Procedures of Real Estate Expropriation (Journal of Laws of 1958, No. 17, item 70, as amended),

- Act of 29 April 1985 year - on Land Management and Real Estate Expropriation (Journal of Laws of 1985, No. 22, item 99, as amended),

Expropriation initially concerned real estate which was occupied for public purposes during the Second World War or intended for such purposes in land use plans after the War. These lands, on the day the Decree of 1948 entered into force, had to be in the possession of their future owners, i.e. the State Treasury, local government unions or companies. Additionally, since 1949, real estate necessary for the realization of national economic plans were also subjected to expropriation. The list of entities authorized to assume ownership rights was long and contained, among others, state authorities and various kinds of national legal persons. After 1958, expropriation could be carried out only for purposes mentioned in the appropriate acts, on behalf of the State Treasury. A special purpose mentioned in these provisions was the realization housing construction. A specific type of expropriation was also the repossession of developed lands on behalf of the State Treasury if the expenses of construction works covered by government funding exceeded half of the technical value of the building ${ }^{15}$.Currently, one can recognize that repossession of real estate by virtue of an Act also takes place as a result of individual action (PARCHOMIUK 2007, p.161). Currently, real estate can become the property of the State Treasury or local government units by virtue of an Act, on the basis of so-called "special acts"(SUCHAR 2012). They make the repossession of real estate designated for the implementation of public purpose investments possible from the day the decision to permit the implementation of a public purpose investment is finalized. There are six "special acts" in force as of now:

- "Special Road Act" that is the Act on special rules regarding the preparation and implementation of investments concerning public roads,

- "Special Railway Act" that is the Act on railway transport,

- "Special Airport Act" that is the Act on special rules regarding the preparation and implementation of investments on public use airports,

- "Special Gas-Port Act" that is the Act on investments connected with the regasified liquefied natural gas terminal in Świnoujście (currently being amended 16 - its content is to cover the construction of transit gas pipelines within the entire country, trans-border connections with pipelines in the Czech Republic, Slovakia and Lithuania, the laying of pipes providing gas to electrical power and heating stations and the construction of new gas compressor stations),

- "Special Flood Act" that is the Act on specific rules regarding the preparation and implementation of investments concerning flood control structures

- "Special Nuclear Act" that is the Act on the preparation and implementation of investments concerning nuclear energy structures and associated investments.

- The protocol when implementing investments in all of the above-mentioned "special acts" is always similar. The authorized entity submits an application to the authority issuing the

\footnotetext{
${ }^{14}$ There are some 380 districts in Poland, being less units than regions. The head of the poviat (district) is called a "starosta" in Polish.

15 art.11 ustawy z 22 kwietnia 1959 r. o remontach i odbudowie oraz o wykańczaniu budowy i nadbudowie budynków (Dz. U. z 1968 r. Nr 36, poz. 249) [Act of 22 April 1959 - on Building Renovations, Completions and Superstructures (Journal of Laws of 1968, No. 36, item 249)]
} 
decision that will make it possible to carry out the investment. The administrative decision (issued in the form of "special acts") accepting the implementation of investments, confirms the location of the investment,

- the divisions of real estate necessary for implementing the investment (within the borders defining the investment area),

- conveying the ownership right to real estate on which the investment is to be implemented on behalf of the State Treasury or local government unit,

- the commencement of construction.

It is also possible to temporarily limit ownership rights to real estate in the following cases, which are specified in separate acts (GONET 2012):

- establishing and maintaining airport ground equipment on land adjacent to the airport ${ }^{17}$,

- separating the necessary area for the protection of surveying, magnetic and gravimetric markers, and triangulation constructions 18 ,

- the occurrence of a non-removable threat of destruction or damage to a cultural monument recorded in the national register ${ }^{19}$,

- the necessity of the compulsory removal of trees or bushes obstructing the visibility of beacons and trains or the exploitation of railway constructions, or ones causing snowdrifts 20 .

\section{Compensations for the deprivation or limitation of rights to real estate}

At present, the issue of compensation for expropriated real estate is regulated by the Act on Real Estate Management ${ }^{21}$. According to this act, compensation should correspond to the value of the deprived rights and can be fulfilled by granting replacement real estate. It is determined by the starost (vide footnote 13) in the expropriation decision, unless the deprivation of rights was the result of subdividing parcels for public roads or the construction of technical infrastructures, or without determining compensation when the applicable regulations call for its determination.

Determining the level of compensation takes place according to the state, use and value of expropriated real estate, on the day the decision regarding expropriation is issued (on the day the deprivation or limitation of rights takes place, on the day of issuing the decision on the division of property, or on the day the resolution regarding the consolidation and parcelling of land is adopted), or its value on the day the decision regarding compensation is issued. This procedure requires the opinion of a property valuer, determining the real estate market value or, in justified cases, its replacement value.

One should keep in mind however, that the constitutional concept of expropriation is broader than that regulated in the provisions of the Act on Real Estate Management (WOLANIN 2008). According to the definition recorded in the Constitution, expropriation takes place for public purposes and with suitable compensation. If the procedure regarding the repossession of the ownership right on behalf of the State Treasury or local government units does not fulfil these conditions, it should be recognized as unlawful (GONET 2012).

At present, one can claim compensation in respect of nationalization or expropriation, depending on the specific case, through administrative procedures or in court. In the case when a decision had been issued, one can submit an application to declare it "null and void" 22. A decision on nationalization or expropriation can be considered unjustified if it had been issued with "flagrant

\footnotetext{
17 art. 86 ust. $2 \div 5$ ustawy z 3 lipca 2002 r. - Prawo lotnicze (Dz. U. z 2013 r. poz. 1393, z późn. zm.) [Air Law of 3 July 2002 (Journal of Laws of 2013, item 1393, as amended)]

18 art. 15 ust. 2 i 3 ustawy z 17 maja 1989 r. - Prawo geodezyjne i kartograficzne (Dz .U. z 2010 r. nr 193, poz. 1287, z poźn. zm.) [Act of 17 May 1989 - Surveying and Mapping Law (Journal of Laws of 2010, No. 193, item 1287, as amended)]

19 art. 50 ust. 3 ustawy z 23 lipca 2003 r. o ochronie zabytków i opiece nad zabytkami (Dz. U. z 2003 r. nr 162, poz. 1568, z późn. zm.) [Act of 23 July 2003 - on the Protection and Conservation of Monuments (Journal of Laws of 2003, No. 162, item 1568, as amended)]

${ }^{20}$ art. 56 ustawy z 28 marca 2003 r. o transporcie kolejowym (Dz. U. z 2013 r. poz. 1594, z późn. zm.) [Act of 18 March 2003 - on Railway Transport (Journal of Laws of 2013, item 1594, as amended)]

21 art. $128 \div 135$ ustawy z 21 sierpnia 1997 r. o gospodarce nieruchomościami (Dz. U. z 2010 r. nr 102, poz. 651, z późn. zm.) [Act of 21 August 1997 - on Real Estate Management (Journal of Laws of 2010, No. 102, item 651, as amended)]

22 art. $417^{1}$ ust. 2 ustawy z 23 kwietnia 1964 r. - Kodeks cywilny (Dz. U. z 2014 r. poz. 121, z późn. zm.) [Act of 24 April 1964 Civil Code (Journal of Laws of 2014, item 121, as amended)]
} 
violation of law" 23 , or contested it if has caused irreversible effects ${ }^{24}$. In the situation when assets were repossessed by an act of law, one should request the decision be issued (e.g. to the starost, in order to establish if the land was justly qualified for nationalization in the case of agricultural lands confiscated in 1994) or exert one's rights in the common court ${ }^{25}$. One can also demand the annulment of the nationalization certificate if it is not in agreement with the current provisions ${ }^{26}$. Determining the appropriate authority will depend on the type of assets he or she was deprived of.

Public authorities are to take responsibility for the damages caused on the basis of the Civil Code. According to it, the compensation of damage can take the form of restoring the previous status, prior to the damage, or the payment of financial damages 27 . The level of compensation should be determined according to prices on the day for which the compensation is determined ${ }^{28}$.

Since in cases dealing with compensation the provisions of the Civil Code are directly applied, administrative procedure is not conducted. Only a declaration of intent is made by the public authority. Determining whether the issued decision was a flagrant violation of law is up to administrative authorities, which act under the supervision of administrative courts. Therefore, the claimant should obtain a suitable administrative decision before the eventuality of taking the case to court (FILIPIAK 2007a).

The Constitution of Poland gives everyone the right to receive compensation for damages caused by the unlawful action of a public authority ${ }^{29}$. Damage should be understood as the difference between the present state of property and the state that would have been if the event causing the damage had not taken place ${ }^{30}$. It can involve reducing assets or increasing liabilities (FILIPIAK, 2007a), and includes losses which the victim suffered, and profits which could have been gained if damage had not been inflicted ${ }^{31}$.

Yet, it was not always so. Before the Constitution of Poland entered into force (on 17 October 1997), one could only attempt to be compensated for the loss of property (FILIPIAK 2007a). Claims at the time were examined on the basis of a former version of the Civil Code (through administrative procedure), which had to be modified after it was deemed incompatible with the Constitution in 200332 . Amendments to the Civil Code took place in $2004{ }^{33}$.

Taking into account the changes to the provisions, responsibility for nationalization and expropriation decisions varies depending on the date they were issued:

1. Before 17 September 1997: the injured party could demand compensation for the damages incurred based on the provisions of the Civil Code in force at the time.

2. Between 17 September 1997 and 1 September 2004: the injured party could demand compensation for the damages incurred and lost profits according to the compulsory provisions of the Civil Code at the time, on the basis of the verdict of the Constitutional Tribunal ${ }^{34}$.

\footnotetext{
${ }^{23}$ art. 156 ust. 2 ustawy z 14 czerwca 1960 r. - Kodeks postępowania administracyjnego (Dz. U. z 2013 r. poz. 267, z późn. zm.) [Act of 16 June 1960 - Code of Administrative Procedure (Journal of Laws of 2013, item 267, as amended)]

${ }^{24}$ art. 158 ust. 2 ustawy z 14 czerwca 1960 r. - Kodeks postępowania administracyjnego (Dz. U. z 2013 r. poz. 267, z późn. zm.) [Act of 16 June 1960 - Code of Administrative Procedure (Journal of Laws of 2013, item 267, as amended)]

25 art. 189 ustawy z 17 listopada 1964 r. - Kodeks postępowania cywilnego (Dz. U. z 2014 r. poz. 101, z późn. zm.) [Act of 17 November 1964 - Code of Civil Procedure (Journal of Laws of 2014, item 101, as amended)]

26 art. 4171 ust. 1 ustawy z 23 kwietnia 1964 r. - Kodeks cywilny (Dz. U. z 2014 r. poz. 121, z późn. zm.) [Act of 24 April 1964 Civil Code (Journal of Laws of 2014, item 121, as amended)]

27 art. 363 ust. 1 ustawy z 23 kwietnia 1964 r. - Kodeks cywilny (Dz. U. z 2014 r. poz. 121, z późn. zm.) [Act of 24 April 1964 Civil Code (Journal of Laws of 2014, item 121, as amended)]

28 art. 363 ust. 2 ustawy z 23 kwietnia 1964 r. - Kodeks cywilny (Dz. U. z 2014 r. poz. 121, z późn. zm.) [Act of 24 April 1964 Civil Code (Journal of Laws of 2014, item 121, as amended)]

${ }^{29}$ art. 77 ust. 1 Konstytucji Rzeczypospolitej Polskiej z 2 kwietnia 1997 r. (Dz. U. z 1997 r. nr 78, poz. 483, z późn. zm.) [Constitution of the Republic of Poland of 2 April 1997 (Journal of Laws of 1997, No. 78, item 483, as amended)]

30 uchwała składu 7 sędziów Sądu Najwyższego z 22 listopada 1963 r, sygn. III PO 31/63 [Resolution of 7 judges of Supreme Court of 22 November 1963]

31 art. 361 ust. 2 ustawy z 23 kwietnia 1964 r. - Kodeks cywilny (Dz. U. z 2014 r. poz. 121, z późn. zm.) [Act of 24 April 1964 Civil Code (Journal of Laws of 2014, item 121, as amended)]

32 Wyrok Trybunału Konstytucyjnego z 23 września 2003 r., sygn. K 20/2002 [Verdict of Constitutional Tribunal of 23 September 2003]

${ }^{33}$ Ustawa z 17 czerwca 2004 r. o zmianie ustawy kodeks cywilny oraz niektórych innych ustaw (Dz. U. z 2004 r. nr 152, poz. 1692) [Act of 17 June 2004 - on Modification of the Act - Civil Code, and some other Acts (Journal of Laws of 2004, No. 152, item 1692)]

34 Wyrok Trybunału Konstytucyjnego z 23 września 2003 r., sygn. K 20/2002 [Verdict of Constitutional Tribunal of 23 September 2003]
} 
3. After 1 September 2004: the injured party can demand compensation for the damages incurred and lost profits, according to the amended Civil Code ${ }^{35}$.

Currently, the effects of the unlawful activities taken by public institutions of the former economic system are being eliminated, thus damages continuing from the mid forties of the XX century dominate in the present proceedings (FILIPIAK 2007b). Injured parties, in such cases, can apply for compensation for the incurred damages (or the return of real estate) as well as for lost profits, but only those after 17 September 1997. The end of the period for calculating lost profits is the date the real estate was returned to the claimant or the date when it was ultimately stated that the payment of compensation would be necessary.

Methods of determining the level of compensation for deprived or limited rights are familiar to and described within the professional community of valuers. However, determining compensation for lost profits does not have such a long tradition in Polish legislation (FILIPIAK 2007b). In both cases, it is necessary to:

- determine the status and use of the real estate on the day the deprivation or limitation or rights to it took place,

- analyze the variability of transaction prices for real estate similar to that which had been lost, for the day compensation is determined.

Additionally in the case of determining the amount of lost profits, the duties of the valuer should include (FILIPIAK 2007b):

- the presentation of the possible way in which the real state was used after 17 September 1997, taking into account the land use plan that applied at that time,

- the determination of the hypothetical status of the real estate within the period of time analyzed for lost profits, after 17 September 1997.

One should remember that lost profits are a claim that is not fulfilled on the basis of the Act on Real Estate Management, and is not taken into account when paying compensation for currently expropriated real estate.

\section{Spatial planning in post-war Poland}

As results from the rules presented above regarding the determination of the level of compensation for incurred losses and lost benefits connected with the deprivation of rights to real estate or their limitation, it is extremely important for the valuer to have an understanding of the provisions (both current and past) concerning spatial planning. This ensures the easy navigation of planning documentation and makes it possible to determine the use of real estate on the day:

- the rights to the real estate were deprived or limited (regardless of when the damage took place),

- the possible type of its use was determined (17 September 1997 and later).

Spatial planning was always a very important element of activities undertaken by rulers (BUCHOWSKA 2011). The first legal bases of planning activities were already created in Poland in the interwar period (Ordinance of $1928{ }^{36}$ and its amendment in 1936 ${ }^{37}$ ). According to the ordinance, development plans (general and detailed) were to be prepared in order to carry out regulation and develop towns in a proper manner. They contained regulation lines, separating areas of different purposes and types of construction as well as building alignments. Gmina (municipal) Councils, Poviat (District) Departments and Executive Departments of Health Resource Committees were appointed to prepare such plans. The change of legislation extended both the spatial extent (to include the voivodeship) and aims of the planning (when it was necessitated by economic and social conditions). The Regional Planning Committee was created.

\footnotetext{
35 Ustawa z 17 czerwca 2004 r. o zmianie ustawy kodeks cywilny oraz niektórych innych ustaw (Dz. U. z 2004 r. nr 152, poz. 1692) [Act of 17 June 2004 - on Modification of the Act - Civil Code and some other Acts (Journal of Laws of 2004, No. 152, item 1692)]

${ }^{36}$ Rozporządzenie Prezydenta Rzeczypospolitej z dnia 16 lutego 1928 r. o prawie budowlanem i zabudowaniu osiedli (Dz. U. 1928 r. nr 23 poz. 202) [Ordinance of President of Poland of 16 February 1928 - on Building Law and Development of Settlements (Journal of Laws of 1928, No. 23, item 202]

37 Ustawa z dnia 14 lipca 1936 r. o zmianie rozporządzenia Prezydenta Rzeczypospolitej z dnia 18 lutego 1928 r. o prawie budowlanym i zabudowaniu osiedli (Dz. U. z 1936 r. nr 56 poz. 405) [Act of 14 July 1936 on Modification of Ordinance - on Building Law and Development of Settlements (Journal of Laws of 1936, No. 56, item 405)]
} 
Circumstances connected with the Second World War and Poland entering into the sphere of dependence on the Soviet Union, strongly impacted spatial politics in the country. The centralization of government entailed a hierarchical model of spatial planning, and the consolidation of state ownership over private ownership stimulated the planning of new investments (BÖHM 2006, pp. 143144). Transformations in agriculture, and the development of industry, infrastructure and housing construction were strongly connected with the processes of nationalization and expropriation taking place at the time.

Planning activities started with the implementation of a new, three-level structure of spatial planning units. It was not until after war that damages were catalogued and Regained Territories identified that spatial development plans started to form (BÖHM 2006, p. 145).

In $1945^{38}$, the Ministry of Reconstruction was established. Thereby, the Minister of Reconstruction became the supreme authority overseeing the planned spatial development of the country. The remaining spatial planning authorities were established by the Decree of $1946{ }^{39}$.

1. Central Office of Spatial Planning (with the head appointed by the President of the National Council on request of the Council of Ministers) and Central Planning Council (as the advisory authority) for creating the national plan.

2. Regional administrations of spatial planning (reporting to the voivodes (provincial governors), with managers appointed by the Minister of Reconstruction) and regional planning council (as the advisory authority) for creating regional plans (covering the area of the voivodeships).

3. Local Spatial Planning Offices (with headquarters in poviat offices and cities serving as poviats) for creating local plans (towns and neighborhoods).

In 194940 , the Ministry of Construction was created in place of the Ministry of Reconstruction and the Central Office of Spatial Planning. Part of their duties were taken over by the Ministry of Public Administration and the National Committee for Economic Planning. This was also the time when Voivodeship Committees of Economic and Spatial Planning were created. The National and Voivodeship Committees assumed tasks connected with spatial planning on the national and regional levels.

Important changes in regards to spatial planning took place every time a new law connected with planning was created (in the years: $1961^{41}, 1984^{42}, 1994^{43}$ and $2003{ }^{44}$ ). These began with determining the general aims and tasks of spatial planning. The aim of spatial planning was to ensure the correct development of the individual areas of the country (while accounting for their mutual relationships) and provide conditions for production growth, the comprehensive fulfilment of the needs of the population, and protection of resources and natural assets. The task itself remained unchanged and was to depend on determining the purpose and type of development for the specific areas. It was implemented, as it is of now, on three levels: national, regional (for voivodeships or their parts) and local (for settlements or their parts). Additionally, the Act introduced execution plans, that is development plans of land parcels or areas on which building investments are anticipated to be carried out created alongside construction projects. The following became the Central authorities dealing with spatial planning: the Planning Commission alongside the Council of Ministers (in the scope of national and regional spatial development) and the Committee for Building, Urban Planning and Architecture (in the scope of local plans). Departments of Spatial Planning were created in Voivodeship Bureaus and National Poviat Councils.

In 1984, it was noticed that spatial planning should also ensure the improvement of society's life and increase the defence capabilities of the country. Planning was determined to be a continuous

\footnotetext{
${ }^{38}$ Dekret z dnia 24 maja 1945 r. o utworzeniu Ministerstwa Odbudowy (Dz. U. z 1945 r.nr 21 poz. 123) [Decree of 24 May 1945 on Ministry of Reconstruction (Journal of Laws of 1945, No. 21, item 123)]

${ }^{39}$ Dekret z dnia 2 kwietnia 1946 r. o planowym zagospodarowaniu przestrzennym kraju (Dz. U. z 1946 r. nr 16 poz. 109) [Decree of 2 April 1946- on the Planned Spatial Development of the Nation (Journal of Laws of 1946, No. 16, item 109)]

40 Ustawa z dnia 27 kwietnia 1949 r. o utworzeniu urzędu Ministra Budownictwa (Dz. U. z 1949 r. nr 30 poz. 216) [Act of 27 April 1949 - on Creating the Ministry of Construction (Journal of Laws of 1949, No. 30, item 216)]

${ }^{41}$ Ustawa z dnia 31 stycznia 1961 r. o planowaniu przestrzennym (Dz. U. z 1961 r. nr 7 poz. 47, z późn. zm.) [Act of 21 January 1961 - on Spatial Planning (Journal of Laws of 1961, No. 7, item 47, as amended)]

${ }^{42}$ Ustawa z dnia 12 lipca 1984 r. o planowaniu przestrzennym (Dz. U. z 1984 r. nr 35 poz. 185, z późn. zm.) [Act of 12 July 1984 on Spatial Planning (Journal of Laws of 1984, No. 35, item 185, as amended)]

${ }^{43}$ Ustawa z dnia 7 lipca 1994 r. o zagospodarowaniu przestrzennym (Dz. U. z 1994 r. nr 89 poz. 415, z późn. zm.) [Act of 7 July 1994 - on Spatial Development (Journal of Laws of 1994, No. 89, item 415, as amended)]

${ }^{44}$ Ustawa z dnia 27 marca 2003 r. o planowaniu i zagospodarowaniu przestrzennym (Dz. U. z 2003 r. nr 80 poz. 717, z pózn. zm.) [Act of 27 March 2003 - on Spatial Planning and Development (Journal of Laws of 2003, No. 80, item 717, as amended)]
} 
process, based on the previous status of development, which also aimed to determine the location of investments. The hierarchic classification of local plans was slightly modified. Regional plans could, from this time, exceed beyond the area of a single voivodeship, and local plans included the areas of towns, gminas, their parts or groups. As an advisory authority for the Council of Ministers, the National Spatial Planning Council was created. The Planning Commission alongside the Council of Ministers (central planning) and Minister of Administration and Spatial Development (regional and local planning) became the central authorities dealing with issues of spatial planning. The plans were created by the Planning Commission (national plan) and public administrative organs on the level of a voivodeship (regional plans) and on a local level (local plans).

The Act of 1994 assumed sustainable development as the basis of planning activities. Spatial development was to account for the requirements of spatial order, urban planning and architecture, architectural and landscape values, the conditions of protecting the natural environments as well as the health and safety of people and assets as well as disabled persons, cultural heritage and cultural goods protection, economic values of the area, and national defence and safety needs. What is important, ownership rights were taken into account for the first time.

In order to determine the principles and trends of the nation's spatial policy, ministers and central authorities conduct analyses and studies, as well as working out ideas and creating programs referring to the issues, needs and aims of the assumed works. Similar elaborations were prepared by the voivodeship self-government authorities in order to determine their determinants and spatial policy trends. Additionally, regional councils created spatial development plans for voivodeships. Poviat authorities can carry out research and analyses regarding the area of the poviat and issues connected with its development.

In a way, an inversion of the hierarchy occurred. The determination of the purpose and conditions of land development was carried out in local land use plans, which was a provision of the gmina created for its whole area or its part. For the first time, the procedure of implementing local plans took public opinion into account. In order to determine spatial policy, the Gmina Council had the duty of implementing the study of the determinants and trends of spatial development. In the case of there not being a land development plan, the Act permits determining the use and rules of spatial development in a decision on land development conditions. Compensation for changes to real estate use covered by a special development plan that is disadvantageous to the owners appeared.

Ustalenie przeznaczenia i zasad zagospodarowania terenu dokonywane było w miejscowych planach zagospodarowania przestrzennego, który był przepisem gminy sporządzanym dla całego jej obszaru albo dla jej części.

At present, the base for spatial planning and development is the Act of 2008. Despite the four-level administrative division of the country, the three-stage system of planning has been preserved. The poviat is practically not involved in planning procedures. A detailed glossary of terms connected with spatial planning was introduced, an attempt was made to partially systematize the symbols on land use plans ${ }^{45}$ and a separate decision locating public purpose investments was established in place of a non-existing land use plan.

\section{Changes of real estate purpose}

Taking into account how the legal determinants spatial planning have changed since the time they started to be released, and how much civilization has developed within this time, it seems only natural that the purpose of the same area could have changed multiple times. During real estate valuation, in order to determine compensation for the deprivation or limitation of rights, it is necessary establish the purpose of real estate at the moment the damage took place. Depending on when this occurred, the valuer should use suitable archival documents to determine the purpose of the real estate. In addition to this, in the event of determining the value of lost profits, it is necessary to verify the real estate purpose on plans which were binding in 1997. Possible changes of real estate purpose have been analyzed on the example of Cracow. The historical background of how land use plans for the area of the city were created has been presented in Table 1.

\footnotetext{
45 Rozporządzenie Ministra Infrastruktury z dnia 26 sierpnia 2003 r. w sprawie wymaganego zakresu projektu miejscowego planu zagospodarowania przestrzennego (Dz. U. z 2003 r. nr 164, poz. 1587) [Ordinance of Minister of Infrastructure of 26 August 2003 - on the Required Scope of the Project of the Local Land Use Plan (Journal of Laws of 2003, No. 164, item 1587]
} 
Table 1

History of creating land use plans - general and detailed (marked in italics) in Cracow

\begin{tabular}{cc}
\hline Year legal basis was issued & $\begin{array}{c}\text { Year of adopting the } \\
\text { plan }\end{array}$ \\
\hline 1928 & 1939 \\
\hline 1946 & - \\
\hline 1961 & 1967,1977 \\
\hline 1984 & 1988,1993 \\
\hline 1994 & $1994,1994-2002$ \\
\hline 2003 & since 2003 until now \\
\hline
\end{tabular}

Source: Own study.

As can be expected, all plans contain a graphic and descriptive part. The graphic part was created on a background map each time. Fragments of the general land use plans from the years 1939 -1994 for parts of the area of Blonia and the University of Science and Technology (Akademia GórniczoHutnicza - AGH) campus have been shown in Figure 1.

This land is located in the center of Cracow. Land use plans created for it established a set direction of development from the very beginning (BIEDA, PARZYCH, 2013), which is clearly visible in the photogrammetric documents (Fig. 2).

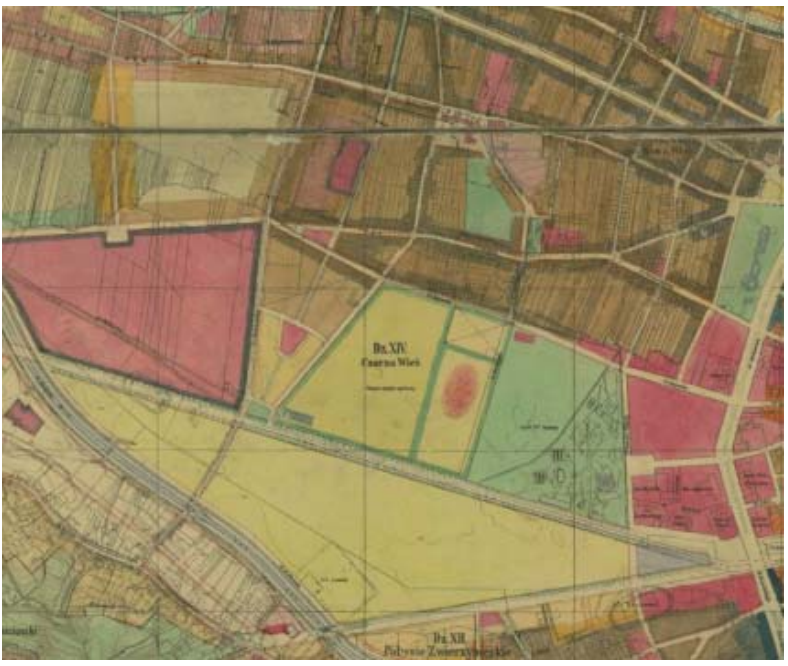

1939

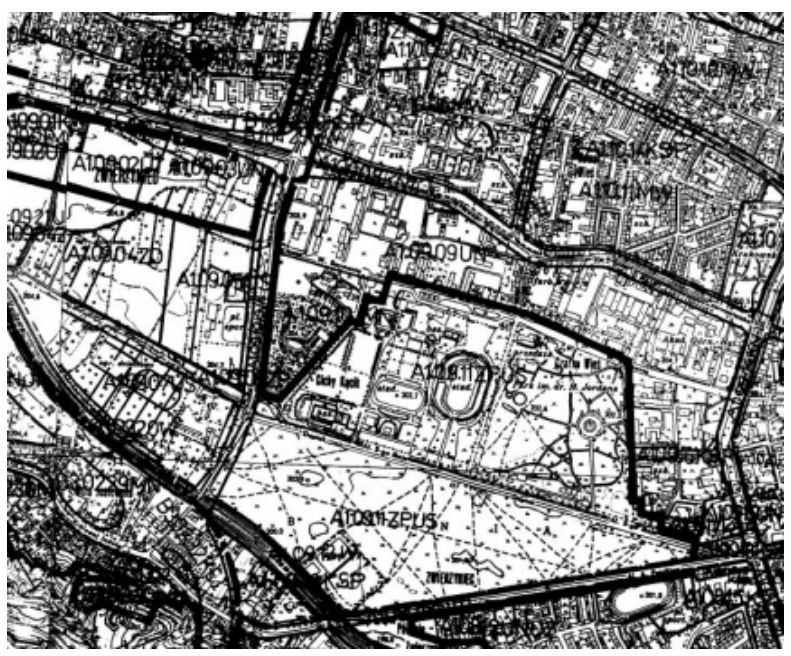

1977

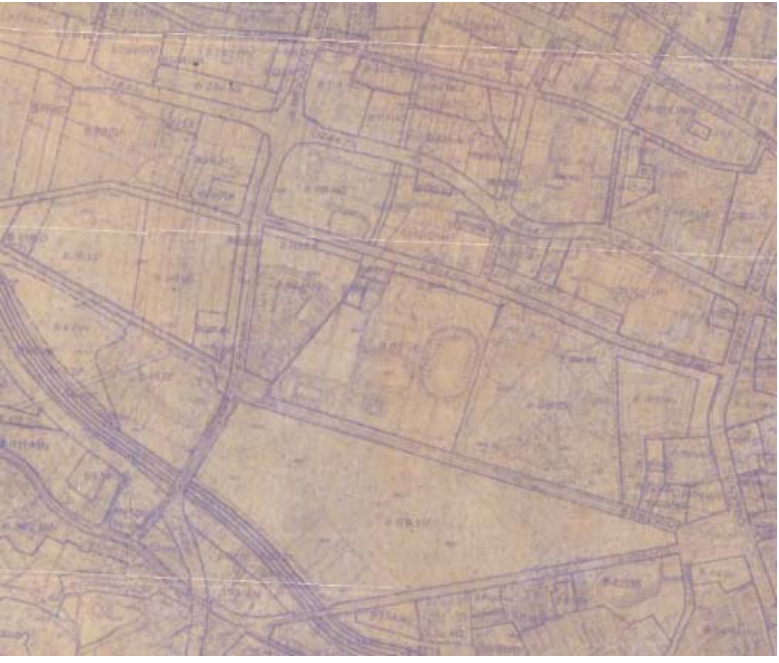

1967

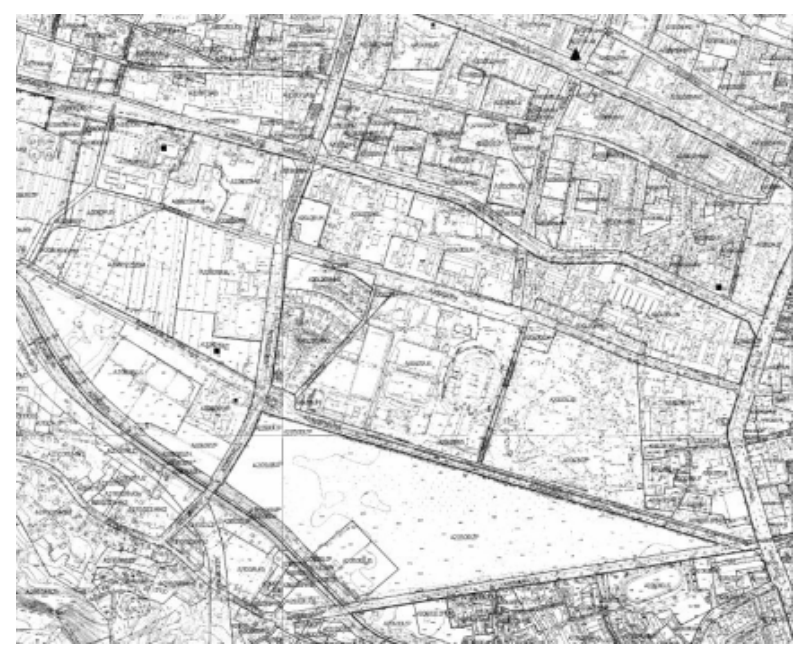

1988 


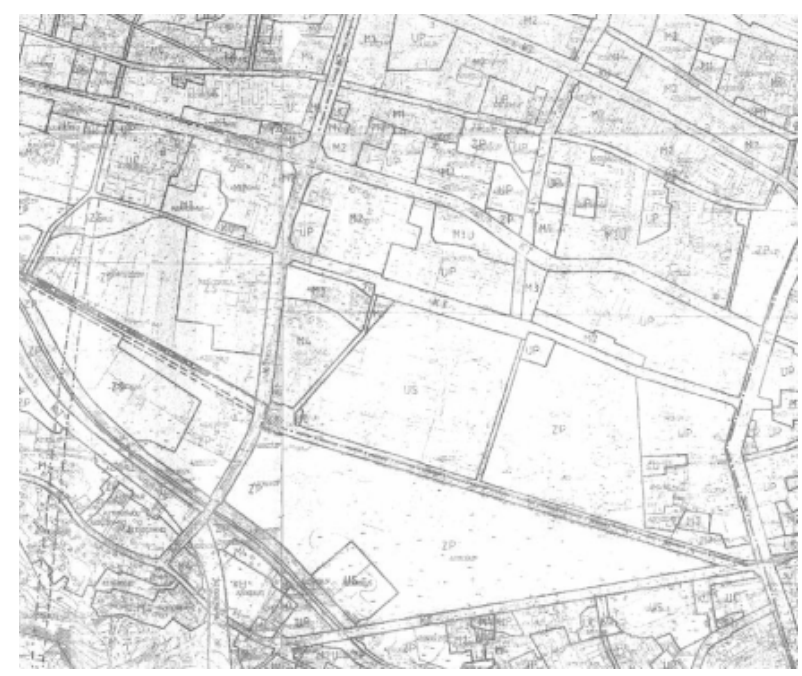

1993

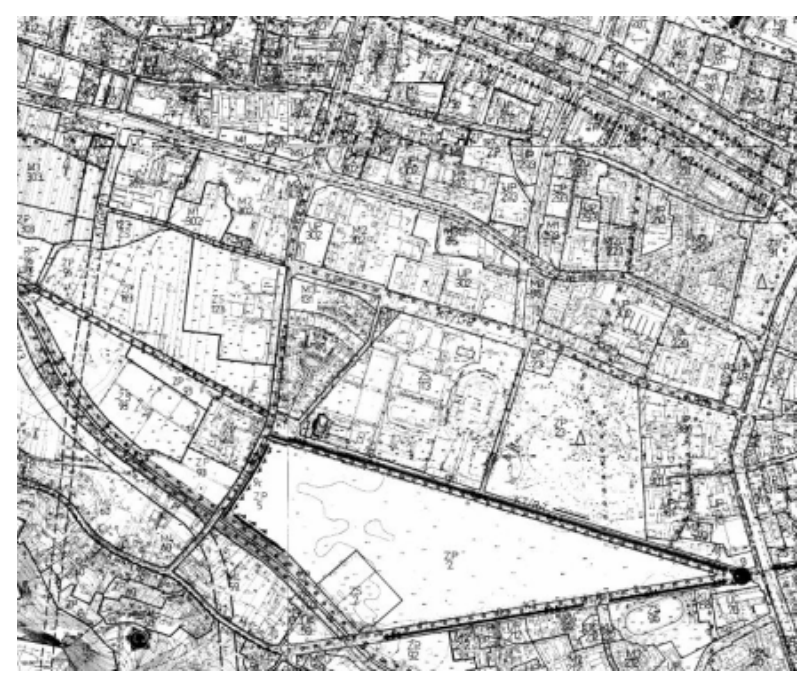

1994

Fig. 1. Comparison of fragments of existing local land use plans for the Blonia area and AGH campus in the years 1939 and 2013. Source: Bulletin of Public Information of Cracow City.

Currently, in addition to the above-mentioned areas of Blonia (red color) and AGH campus (yellow color) the area includes: sports facilities of the Wisla Sports Association and Cracovia Sports Club, dr. Henryk Jordan's park, facilities of the Jagiellonian University - Uniwersytet Jagielloński (including the Jagiellonian Library) and buildings of the National Museum in Cracow. Low singlefamily housing and high multi-family housing as well as allotment gardens can also be found here.

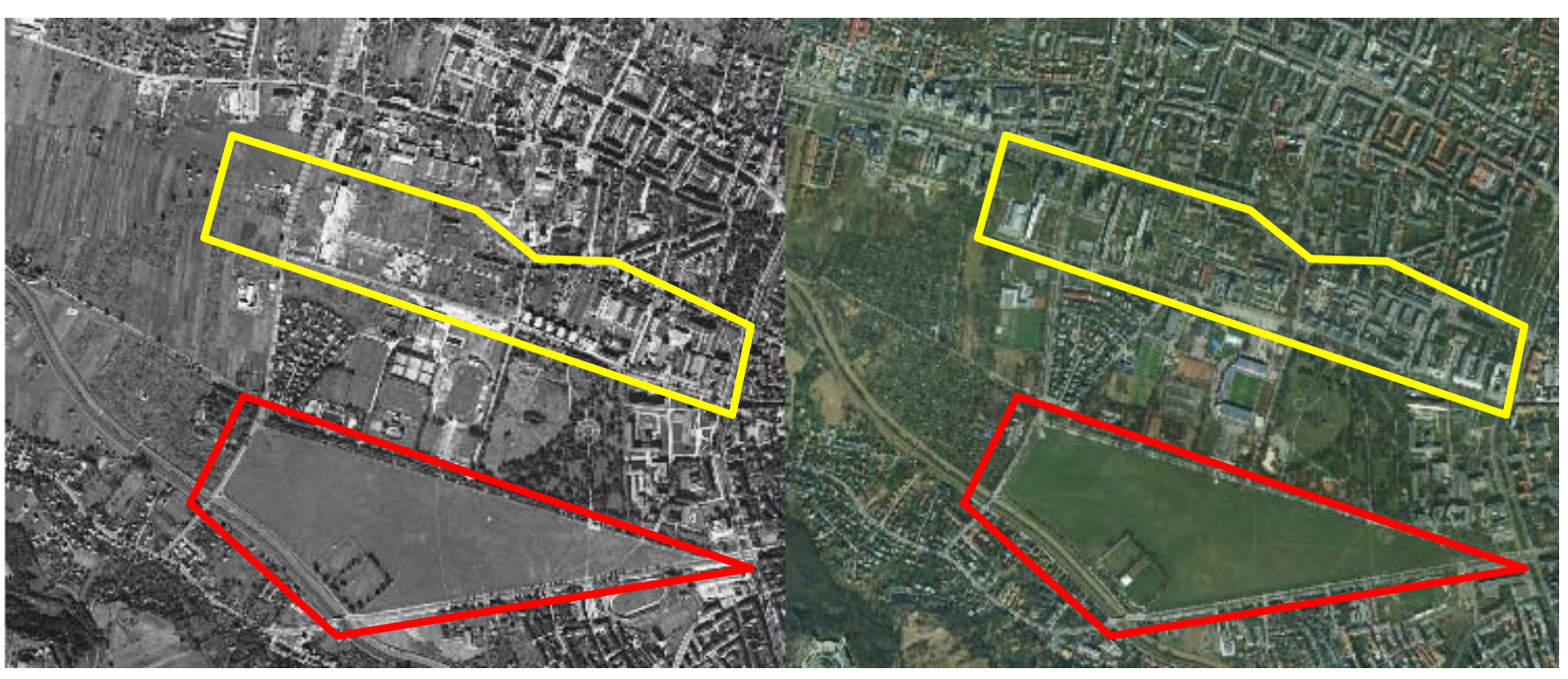

Fig. 2. Comparison of satellite photos from 1965 and orthophotomap from 2009 for the area of Blonia and the AGH campus. Source: Bulletin of Public Information of Cracow City.

The main pavilion of AGH is visible on the first existing general plan from 1939. Nevertheless, only part of the present campus is marked on it as land designated for development connected with education, culture, sport and recreation (pink color). What is nowadays Blonia, similarly to the areas of garden allotments located near its western border, was an area zoned for agriculture production. The area between them was additionally zoned for urban greenery.

The plan from 1967 divided the area of AGH into fragments, the majority of which were occupied by educational buildings. However it also set apart residential areas (dormitories marked as housing complexes) and areas of greenery. Additionally it was planned that in the future, the university would invest in the housing found in the western part of the complex. Blonia was marked as an area of public greenery. Its development and division were forbidden and the existing sports field was to be relocated. Garden allotments and agricultural lands on the western side of Blonia were to be 
transformed into park greenery and developed as a city swimming pool. Between objects belonging to the Jagiellonian University, a city hotel was to be created. All these changes were to be carried out by the year 1970.

The next plan was not as detailed. In 1977, the entire analyzed area was occupied practically by four fields of use: educational services, public greenery, sports facilities and housing. In 1988, the previous assumptions were returned to and, despite changes in provisions connected with spatial planning, it remained so in all the following general plans.

Only a study of the determinants and trends of development for this area from 200346 is available at present. One of its graphic appendixes shows the present status of the development of this area (Fig. 3a). Colors representing public services (pink), residential housing (orange) and city greenery and sport (green) clearly dominate. Detailed land use plans are being on the basis of this study. Because there is no statutory duty to create plans, they cover the analyzed area in a small extent (Fig. $3 b$ and $3 c)$.

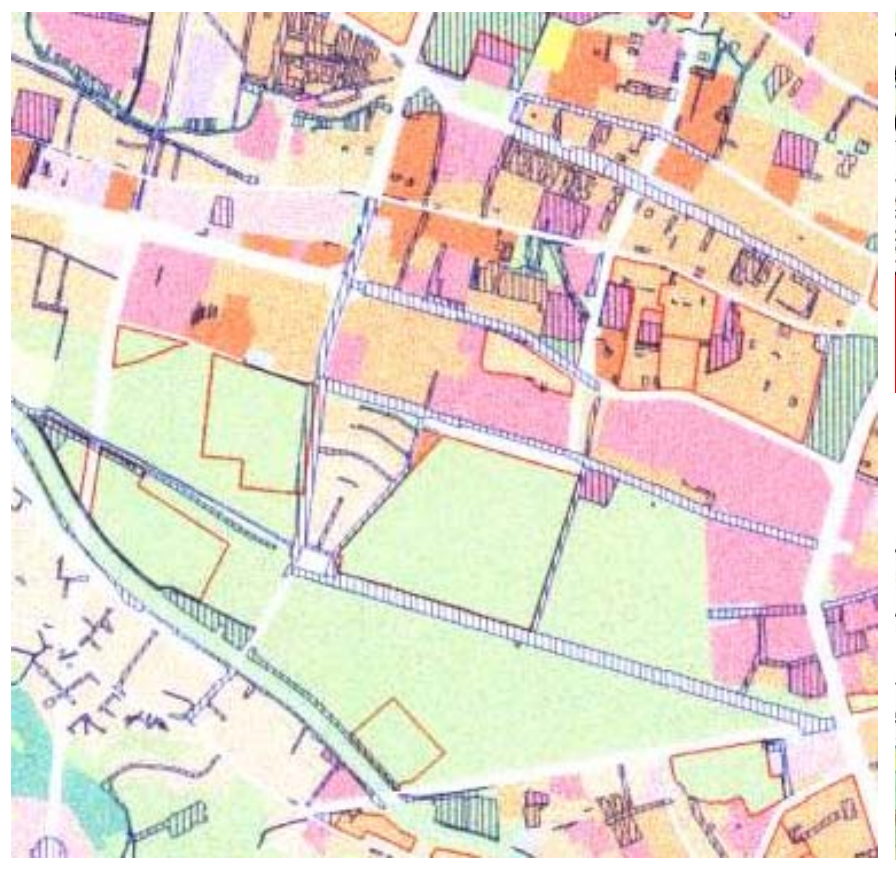

a

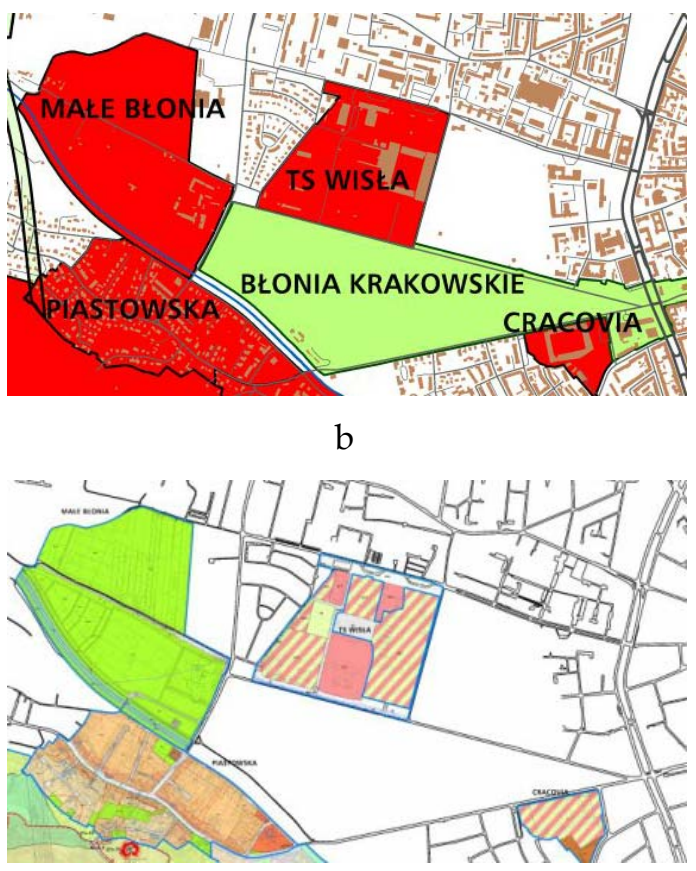

C

Fig. 3. Present planning documents for the Blonia and AGH campus areas: a - Study of Determinants and Trends of Spatial Development,

$\mathrm{b}$ - area of existing (red color) land use plans and those being created (green color),

c - existing land use plans, Source: Bulletin of Public Information of Cracow City

One should note that the greatest differences in the designated real estate use within the analyzed area took place between the plans from the years 1939 and 1967. This is, without a doubt, the effect of the expansion of the city and the time that passed between the individual versions of the document were created. Despite the fact that the observed changes cannot be deemed spectacular (agricultural lands changed to public greenery or garden allotments, or residential areas rezoned for educational services), they could easily distort the results of valuation, especially that in this case, all nationalization activities took place during the time that the plan which differed most significantly from the current planning documents was in effect.

\section{Conclusions}

Valuations of nationalized and expropriated real estate carried out in order to determine compensation are extremely difficult because of the necessity to determine the designated use and

${ }^{46}$ Uchwała Rady Miasta Krakowa Nr XII/87/03 z dnia 16 kwietnia 2003 r. zmieniona uchwałą Nr XCIII/1256/10 z dnia 3 marca 2010 r. w sprawie Studium Uwarunkowań i Kierunków Zagospodarowania Przestrzennego Miasta Krakowa [Resolution of Cracow City Council of 16 April 2003 Modified by Resolution of 3 March 2010 - regarding the Study of Determinants and Trends of Spatial Development of Cracow City of 3 March 2010] 
state of the real estate in the often quite distant past, that is at the moment the rights to it were deprived or limited, and at the moment when one can start calculating the amount of lost profits that the owner could have obtained if he or she possessed the real estate.

The aim of paper is familiarize the reader with the issue of determining the historic purpose of real estate. Yet, this feature is not subjective and does not depend solely on the valuer, who cannot determine the purpose of the real estate alone and must make use of planning documentation. In the case of establishing the historic purpose of real estate, this is archival documentation. The authors conceive that in order to find suitable documents, one should be familiar with the legal bases of their creation. Thus, the work contains an analysis of all Polish normative acts concerning spatial planning and development.

The incorrect determination of real estate purpose can also lead to its erroneous valuation, and consequently, the inaccurate calculation of compensation. As a result, the dissatisfied injured party can contest the valuation. Differences in prices of real estate grouped depending on the possibilities of their development are the best example of just how big of an error can be made in the final value of real estate when purpose is determined incorrectly. A compilation of average transaction prices of land property in Cracow has been presented in Table 2. Due to the lack of other statistic data, the data are from the year 2012.

Average prices of land property in Cracow based on zoning (PLN/1m²)

\begin{tabular}{|c|c|c|c|c|c|}
\hline $\begin{array}{l}\text { Area of } \\
\text { Cracow }\end{array}$ & $\begin{array}{l}\text { Multi-housing } \\
\text { development / } \\
\text { housing-service }\end{array}$ & $\begin{array}{c}\text { Single-family } \\
\text { housing } \\
\text { development }\end{array}$ & $\begin{array}{l}\text { Industrial } \\
\text { lands }\end{array}$ & $\begin{array}{l}\text { Commercial } \\
\text { development } \\
\text { - hotels and } \\
\text { office blocks }\end{array}$ & $\begin{array}{c}\text { Commercial } \\
\text { development } \\
\text { - business } \\
\text { objects }\end{array}$ \\
\hline Srodmieście & 2,200 & - & - & \multirow{4}{*}{2,250} & \multirow{4}{*}{900} \\
\hline Krowodrza & 1,200 & 470 & - & & \\
\hline Podgorze & 1,100 & 260 & 175 & & \\
\hline Nowa Huta & 800 & 125 & 135 & & \\
\hline
\end{tabular}

Source: Bulletin of Public Information of Cracow City.

The differences in prices are evident, with real estate zoned for commercial development, hotels and office blocks being evidently the most expensive. On the opposite end is industrial real estate. This means that, in the worst case, incorrectly determined real estate purpose can result in an error in the magnitude of a few million PLN when calculated for a medium-sized parcel (a dozen or so ars). Agricultural land was not accounted for, because if it is in a marketable location, it is sold at the price of parcels designated for development. Others types, usually in big towns, do not sell.

\section{References}

BIEDA A., PARZYCH P., 2013, Development of spatial politics of monumental towns based on Krakow example, SGEM2013 Conference Proceedings, Vol. 2, pp. 143-150

BIEDA A., HANUS P., HYCNER R., 2012, Geodezyjne aspekty planowania przestrzennego $i$ wybranych opracowań projektowych (Surveying aspects of land use planning and selected design studies), Wydawnictwo Gall, Katowice

BÖHM A., 2006, Planowanie przestrzenne dla architektów krajobrazu: o czynniku kompozycji (Spatial planning for landscape architects: about compositional factor), Wydawnictwo PK

BIULETYN Informacji publicznej Miasta Kraków (Bulletin of Public Information of Krakow City) [http://www.bip.krakow.pl]

BUCHOWSKA M., 2011, Odbudowa powojenna wsi województwa krakowskiego w świetle archiwalnych źródet regionalnej dyrekcji planowania przestrzennego (Reconstruction of the postwar village in the province of cracow basis on the regional planning management's archival documents), Infrastruktura i Ekologia Terenów Wiejskich, No. 01

CYMERMAN R. (red.), 2011, Planowanie przestrzenne dla rzeczoznawców majatkowych, zarządców oraz pośredników w obrocie nieruchomościami (Spatial planning for valuers, administrators and agents in real estate turnover), Wydawnictwo Educaterra, Olsztyn 
DEKRET Polskiego Komitetu Wyzwolenia Narodowego z 12 grudnia 1944 r. o przejęciu niektórych lasów na własność Skarbu Państwa (Dz. U. z 1944 r. nr 15 poz. 82) [ Decree of Polish Commitee of National Liberation of 12 December 1944- about repossession some forests on the benefit of State Treasury (Journal of Laws of 1944, No. 15, item 82)]

DEKRET Polskiego Komitetu Wyzwolenia Narodowego z 6 września 1944 r. o przeprowadzeniu reformy rolnej (Dz. U. z 1944 r. nr 4 poz. 17, z późn. zm.) [ Decree of Polish Commitee of National Liberation of 6 September 1944 - about performance of agrarian reform (Journal of Laws of 1944, No. 4, item 17, as amended)]

DEKRET z 24 maja 1945 r. o utworzeniu Ministerstwa Odbudowy (Dz. U. z 1945 r.nr 21 poz. 123) [Decree of 24 May 1945 - about Ministry of Reconstruction (Journal of Laws of 1945, No. 21, item 123)]

DEKRET z 26 października 1945 r. o własności i użytkowaniu gruntów na obszarze m. st. Warszawy (Dz. U. 1945 r. nr 50, poz. 279) [Decree of 26 October 1945 - about lands ownership rigth and use within area of capital city Warsaw (Journal of Laws of 1945, No. 50, item 273)]

DEKRET z 8 marca 1946 r. o majątkach opuszczonych i poniemieckich (Dz. U. z 1946 r. nr 13, poz. 87) [Decree of 8 March 1946 - about abandoned estates and formerly owned by Germans (Journal of Laws of 1946, No. 13, item 87)]

DEKRET z dnia 2 kwietnia 1946 r. o planowym zagospodarowaniu przestrzennym kraju (Dz. U. z 1946 r. nr 16 poz. 109) [Decree of 2 April 1946- about scheduled country development (Journal of Laws of 1946, No. 16, item 109)]

FILIPIAK J., 2007a, Czynności rzeczoznawcy majątkowego przy określaniu wartości utraconych korzyści, cz. I (Activities of valuer by determination of lost profits, part I), Nieruchomości, No. 9 (109)

FILIPIAK J., 2007b, Czynności rzeczoznawcy majątkowego przy określaniu wartości utraconych korzyści, cz. II (Activities of valuer by determination of lost profits, part II), Nieruchomości, No. 10 (110)

GONET M., 2012, Wywtaszczanie nieruchomości w rozumieniu ustawy o gospodarce nieruchomościami (Real estate expropriation within the meaning of the Act - about real estate management), Nieruchomości, No. 12

KonStYTUCja Rzeczypospolitej Polskiej z 2 kwietnia 1997 r. (Dz. U. z 1997 r. nr 78, poz. 483, z późn. zm.) [Constitution of the Republic of Poland of 2 April 1997 (Journal of Laws of 1997, No. 78, item 483, as amended)]

MENDELSON M.H., 1985, Compensation for Expropriation: The Case Law, American Journal of International Law, Vol. 79, No. 2, pp. 414-420

Muller M.H., 1981, Compensation for Nationalization: A North-South Dialogue, Columbia Journal of Transnational Law, Vol. 19, pp. 35-78

MZYK M., 2008, Wywtaszczenia na cele specjalne (Expropriations for special purposes), Materiały $\mathrm{z}$ seminarium polsko-brytyjskiego nt. Odszkodowanie za wywłaszczenie nieruchomości - aktualna praktyka i pożądane kierunki zmian, Warszawa

NosAL E., 2001, The taking of land: market value compensation should be paid, Journal of Public Economics, Vol. 82, No. 3, pp. 431-443

ORZECZENIE Trybunału Konstytucyjnego z 28 maja 1991 r., sygn. K1/91 [Verdict of Constitutional Tribunal of 28 May 1991]

PARCHOMIUK J., 2007, Odpowiedzialność odszkodowawcza za legalne działania administracji publicznej (Compensational responsibility for legal activities of public administration), Wydawnictwo C. H. Beck

ROZPORZĄDZENIE Ministra Infrastruktury z dnia 26 sierpnia 2003 r. w sprawie wymaganego zakresu projektu miejscowego planu zagospodarowania przestrzennego (Dz. U. z 2003 r. nr 164, poz. 1587) [Ordinance of Minister of Infrastructure of 26 August 2003 - in case of demanded contents of project of local land use plan (Journal of Laws of 2003, No. 164, item 1587]

RozPORZĄDzEnIE Prezydenta Rzeczypospolitej z dnia 16 lutego 1928 r. o prawie budowlanem i zabudowaniu osiedli (Dz. U. 1928 r. nr 23 poz. 202) [Ordinance of President of Poland of 16 February 1928 - about building law and settlements development (Journal of Laws of 1928, No. 23, item 202]

SCHACHTER O., 1984, Compensation for expropriation: the case low, American Journal of International Law, Vol. 78, No. 1, pp. 121-130

SUCHAR T., 2012, Wywtaszczenie na gruncie Konstytucji RP z 1997 r. (Expropriation within Constitution of Pland of 1997), Nieruchomości, No. 09 
ŚLIWIŃSKI Ł., 2011, Odszkodowania za nieruchomości przeznaczone pod drogi publiczne (Compensation for property intended for public roads), Studia i Materiały Towarzystwa Naukowego Nieruchomości, Vol. 19, No. 4, pp. 191-202

UstAWA z dnia 14 lipca 1936 r. o zmianie rozporządzenia Prezydenta Rzeczypospolitej z dnia 18 lutego 1928 r. o prawie budowlanem i zabudowaniu osiedli (Dz. U. z 1936 r. nr 56 poz. 405) [Act of 14 July 1936 about modification of Ordinance - about building law and settlements development (Journal of Laws of 1936, No. 56, item 405)]

UstAWA z dnia 27 kwietnia 1949 r. o utworzeniu urzędu Ministra Budownictwa (Dz. U. z 1949 r. nr 30 poz. 216) [Act of 27 April 1949 - about creating of Minister of Structure office (Journal of Laws of 1949, No. 30, item 216)]

USTAWA z 25 lutego 1958 r. o uregulowaniu stanu prawnego mienia pozostającego pod zarządem państwowym (Dz. U. z 1958 r. nr 11 poz. 37, z późn. zm.) [Act of 25 February 1958 - about regulation of legal status of assets being under State administration (Journal of Laws of 1958, No. 11 , item 37, as amended)]

USTAWA z 22 kwietnia 1959 r. o remontach i odbudowie oraz o wykańczaniu budowy i nadbudowie budynków (Dz. U. z 1968 r. Nr 36, poz. 249). [Act of 22 April 1959 - about buildings renovations, completing and superstructures (Journal of Laws of 1968, No. 36, item 249)]

USTAWA z 14 czerwca 1960 r. - Kodeks postępowania administracyjnego (Dz. U. z 2013 r. poz. 267, z późn. zm.) [Act of 16 June 1960 - Code of Administrative Procedure (Journal of Laws of 2013, item 267, as amended)]

USTAWA z dnia 31 stycznia 1961 r. o planowaniu przestrzennym (Dz. U. z 1961 r. nr 7 poz. 47, z późn. zm.) [Act of 21 January 1961 - about spatial planning (Journal of Laws of 1961, No. 7, item 47, as amended)]

USTAWA z 23 kwietnia 1964 r. - Kodeks cywilny (Dz. U. z 2014 r. poz. 121, z późn. zm.) [Act of 24 April 1964 - Civil Code (Journal of Laws of 2014, item 121, as amended)]

UstAWA z 17 listopada 1964 r. - Kodeks postępowania cywilnego (Dz. U. z 2014 r. poz. 101, z późn. zm.) [Act of 17 November 1964 - Code of Civil Procedure (Journal of Laws of 2014, item 101, as amended)]

USTAWA z dnia 12 lipca 1984 r. o planowaniu przestrzennym (Dz. U. z 1984 r. nr 35 poz. 185, z późn. zm.) [Act of 12 July 1984 - about spatial planning (Journal of Laws of 1984, No. 35, item 185, as amended)]

USTAWA z 17 maja 1989 r. - Prawo geodezyjne i kartograficzne (Dz .U. z 2010 r. nr 193, poz. 1287, z poźn. zm.) [Act of 17 May 1989 - Surveying and Mapping Law (Journal of Laws of 2010, No. 193, item 1287, as amended)]

USTAWA z dnia 7 lipca 1994 r. o zagospodarowaniu przestrzennym (Dz. U. z 1994 r. nr 89 poz. 415, z późn. zm.) [Act of 7 July 1994 - about spatial development (Journal of Laws of 1994, No. 89, item 415 , as amended)]

USTAWA z 21 sierpnia 1997 r. o gospodarce nieruchomościami (Dz. U. z 2010 r. nr 102, poz. 651, z późn. [Act of 21 August 1997 - about real estate management (Journal of Laws of 2010, No. 102, item 651, as amended)]

UstaWA z 13 października 1998 r. - Przepisy wprowadzające Ustawa reformującej administrację publiczną (Dz. U. z 1998 r. nr 872, poz. 133, z późn. zm.) [Provisions of 13 October 1998 introducing acts reforming public administration (Journal of Laws of 1998, No. 872, item 133, as amended)]

UstaWA z 3 lipca 2002 r. - Prawo lotnicze (Dz. U. z 2013 r. poz. 1393, z późn. zm.) [Air law of 3 July 2002 (Journal of Laws of 2013, item 1393, as amended)]

USTAWA z dnia 27 marca 2003 r. o planowaniu i zagospodarowaniu przestrzennym (Dz. U. z 2003 r. nr 80 poz. 717, z pózn. zm.) [Act of 27 March 2003 - about spatial planning and development (Journal of Laws of 2003, No. 80, item 717, as amended)]

USTAWA z 28 marca 2003 r. o transporcie kolejowym (Dz. U. z 2013 r. poz. 1594, z późn. zm.) .) [Act of 18 March 2003 - about railway transport (Journal of Laws of 2013, item 1594, as amended)]

USTAWA z 23 lipca 2003 r. o ochronie zabytków i opiece nad zabytkami (Dz. U. z 2003 r. nr 162, poz. 1568, z późn. zm.) [Act of 23 July 2003 - about monuments protection and conservation of monuments (Journal of Laws of 2003, No. 162, item 1568, as amended)] 
USTAWA z 17 czerwca 2004 r. o zmianie Ustawa kodeks cywilny oraz niektórych innych ustaw (Dz. U. z 2004 r. nr 152, poz. 1692) [Act of 17 June 2004 - about modification of Act - Civil Code and some other Acts (Journal of Laws of 2004, No. 152, item 1692)]

TREMBeCKA A., KWARTNIK-PRUC A., 2010, The issue of compensation for loss of rights to property plots parcelled out for public roads based on the example of Cracow, Geomatics and Environmental Engineering, Vol. 4, No. 4, pp.105-112

WALACIK M., 2011, Utracone korzyści a stuszne odszkodowanie za nieruchomości przejęte pod inwestycje celu publicznego $w$ Polsce i na świecie (Lost profits and just compensation for properties taken over for public purpose investments in Poland and other countries), Studia i Materiały Towarzystwa Naukowego Nieruchomości, Vol. 19, No. 3, pp. 107-118

WierzBOWSKi M. (red.), 2011, Prawo administracyjne (Administrative law), Wydawnictwo Prawnicze Lexis Nexis

Wolanin M., 2008, Nacjonalizacja działek drogowych przy podziale nieruchomości, cz. I (Nationalization of roads parcels by real estate subdivision), Nieruchomości, No. 10 (122)

WYrOK Trybunału Konstytucyjnego z 21 czerwca 2005 r., sygn. P25/02 [Verdict of Constitutional Tribunal of 21 June 2005]

WYROK Trybunału Konstytucyjnego z 23 września 2003 r., sygn. K 20/2002 [Verdict of Constitutional Tribunal of 23 September 2003]

ŹRÓBEK S., 2008, Procedury wyceny odszkodowań za wywtaszczone nieruchomości w Polsce na tle procedur w innych krajach Unii Europejskiej (Procedures of valuation of compensations for expropriated real estates present practice and desired trends), Materiały z seminarium polsko-brytyjskiego nt. Odszkodowanie za wywłaszczenie nieruchomości - aktualna praktyka i pożądane kierunki zmian, Warszawa

ŹRÓBEK S., WALACIK M., 2008, Analiza porównawcza wybranych zagadnień wywłaszczania nieruchomości w Polsce i za granica (Comparative analysis of selected issues concerning expropriation of real estates in Poland and abroad), Przegląd Geodezyjny, No. 80, pp. 4-9

ŹRÓBEK S., ŹRÓBEK R., 2008, Is The Amount of Compensation for Real Estate Expropriation Just? Current State and Proposals for Changes, Nordic Journal of Surveying and Real Estate Research, Vol. 3, pp. 191-199 